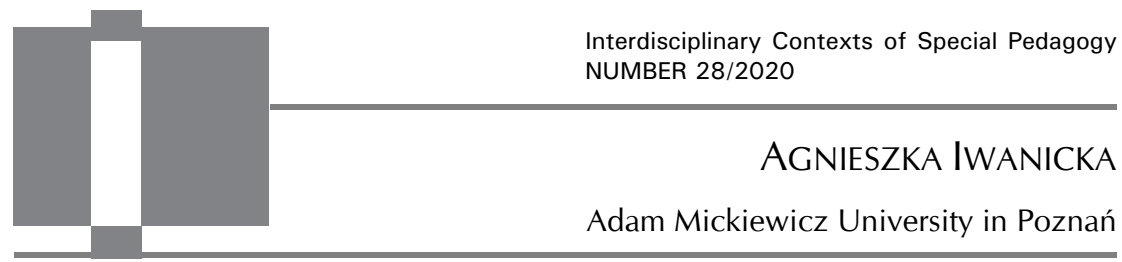

\title{
Loneliness as a potential consequence of the presence of children in the digital world
}

ABSTRACT: Agnieszka Iwanicka, Loneliness as a potential consequence of the presence of children in the digital world. Interdisciplinary Contexts of Special Pedagogy, no. 28, Poznań 2020. Pp. 61-76. Adam Mickiewicz University Press. ISSN 2300-391X. e-ISSN 2658-283X. DOI: https:// doi.org/10.14746/ikps.2020.28.04

The feeling of loneliness is a condition that affects not only adults and youth, but also children. It may be a temporary and transient in nature, occurring as a response to external circumstances, although it can also be long-lasting, as long as months and years, and be a result of deep, traumatic childhood experiences. One of its most common sources is isolation of a child in a family, peer groups and at school. In the article, the author considersnwhether the sense of loneliness experienced by children can also be traced back to the media and the functioning of children in the digital environment. Thanks to the conductednqualitative study (focus interviews with children), the paper answers questions regarding how early school-age children perceive loneliness and isolation, and whether they link this phenomenon with digital media.

KEY WORDS: digital world, children and loneliness, new technology

\section{Introduction}

Early school-age children feel right at home in the digital world - from an early age, they can see adults who use digital media, and their habits and behaviours contribute to the increasingly common 
and earlier use of ICT by children. ${ }^{1}$ However, they rarely possess enough media competence to know that the use of new technologies can lead children to a kind of a digital trap - by opening the door to the world of endless possibilities by facilitating communication, education and access to entertainment, they can at the same time negatively impact the social development of a child, disrupt their interpersonal relationships established in that period in their lives, and even cause them to experience a growing sense of loneliness and isolation. Loneliness in children is a significant issue, which gives rise to a number of long-term negative outcomes. Research shows that even small children perfectly understand the meaning of the concept of loneliness. ${ }^{2}$ The author was curious whether the sense of loneliness experienced by some children could be linked to the fact that they are exposed to the media throughout their development, and this hypothesis formed the basis of the study. In order to respond to the research question posed, the author carried out a qualitative study in the form of focus interviews with primary education students attending integration classes. The aim of the study was to examine and describe whether the digital environment and the use of new technologies can contribute to a sense of loneliness among early school-age children.

The problem of loneliness and isolation of children is quite often discussed in literature, ${ }^{3}$ usually it is brought up in the context of

${ }^{1}$ D. Batorski, “Technologie i media w domach i życiu Polaków”, [in:] Diagnoza społeczna 2015: Warunki i jakość życia Polaków, J. Czapiński, T. Panek (eds.), Rada Monitoringu Społecznego, Warsaw, 2015; J. Pyżalski, A. Zdrodowska, Ł. Tomczyk, Polskie badania EU Kids Online 2018. Najważniejsze wyniki i wnioski, Fundacja Orange, Warsaw, 2019

2 Cf. J. Cassidy, S.R. Asher, Loneliness and peer relations in youth children. Child Development, 63(2), 1992, pp. 350-365; G.W. Ladd, B.J. Kochenderfer, C.C. Coleman, Friendship quality as a predictor of young children's early school adjustment, 67(3), 1996, pp. 1103-1118.

${ }^{3}$ H. Cudak, Szkice z badań nad rodzina, Wyższa Szkoła Pedagogiczna Kielce, Kielce, 1995, p. 8, 45; H. Izdebska, “Współżycie pokoleń w rodzinie”, Problemy opiekuńczo-wychowawcze, 1980, no. 9; J. Cassidy, S.R. Asher, Loneliness and peer relations in youth children. Child Development, 63(2), 1992, pp. 350-365. 
dysfunctional families, characterised by the weakening of the emotional bond between its members, ${ }^{4}$ the lack of psychological bonds between them, ${ }^{5}$ or the lack of broadly understood support that a child should receive from its parents. Some authors point out that that more and more often parents are absent from their children's experiences, which may cause them to feel lonely. ${ }^{6}$ This absence can be both physical (caused by long working hours, apparent lack of time for the child, exhaustion) but also emotional (rejection of the child's needs in favour of their own, excessive involvement in other matters - professional and social life, as well as excessive use of media at the expense of time spent with the child). However, to date, there were no studies, which would attempt to capture the relationship between loneliness and the functioning of children in the digital world. The study carried out by the author are an attempt at filling the gap in this research area, as the author believes that the awareness of the link between the feeling of isolation with digital media should become a permanent part of the subject of media pedagogy studies and be a concern for media educators, teachers and parents. This will allow them to take appropriate measures to support children facing this issue, while enabling them to change their situation. Perhaps the topic of loneliness in children and its links with digital media should be even referred to in the core curriculum of primary schools.

\section{Loneliness and isolation in the digital world}

In spite of the fact that loneliness can affect a person at any stage of their development, it is least associated with childhood. Mean-

${ }^{4}$ H. Cudak, Szkice z badań nad rodzina, Kielce, 1995, p. 8, 45.

${ }^{5}$ G. Gajewska, "Opuszczenie i osamotnienie dziecka wśród dorosłych”, [in:] Nowe stulecie dziecku, G. Gajewska, D. Waloszek, (eds.) Zielona Góra, 2001, p. 267.

${ }^{6}$ E. Kozdrowicz, "Dziecko zagubione w rzeczywistości", [in:] Nowe stulecie dziecku, G. Gajewska, D. Waloszek, (eds.) Zielona Góra, 2001, pp. 258-260. 
while, in reality children also experience loneliness or a sense of isolation in their closest family and peer circles.

The analysis of available sources makes it possible to distinguish between the concepts of loneliness and isolation. In certain situations not only adults but also children consciously seek isolation, and they do so for various reasons: to rethink their emotions, to gain distance from problems, to plan for the future. Thus, isolation understood in this way is a state resulting from one's own choice: desirable and necessary for one's personal development. ${ }^{7}$ According to Szczepański, isolation is a feeling of lack of contact with other people and oneself. ${ }^{8}$ It means experiencing loneliness, understood as physical distance from others, subjective mental experiences, feeling of lack of bond with other people, as well as oneself. ${ }^{9}$ Thus, understood this way, it constitutes "a limitation of an individual's development, a disturbance of their normal functioning, a burden on life experience [...]"10 The feeling of isolation may be deepened in the cases where interpersonal contacts with other people are disrupted, when people feel that nobody thinks or remembers them, when they are treated by other members of our development environment in a subjective way. ${ }^{11}$ This is most often understood as a result not so much of internal limitations as of external situations or conditions people operate in. In the case of children, in particular the youngest ones, loneliness will usually be conflated with isolation. It is seldom their own choice, because it stands in opposition to their developmental needs, rather it is a sum of unfavourable envi-

7 I. Niewiadomska, “Osamotnienie - sprzyja toksykomanii”, Problemy Alkoholizmu, Warsaw, 1994, no. 8-9, p. 13.

8 J. Szczepański, Sprawy ludzkie, Wydawnictwo Czytelnik, Warsaw, 1980, p. 23.

9 B. Matyjas, Źródła prowadzące do osamotnienia dziecka w rodzinie, Wydawnictwo Uniwersytetu Jana Kochanowskiego Kielce, Kielce, 2011.

10 E. Dubas, “Samotność i osamotnienie jako wyznacznik dla dzisiejszej edukacji", [in:] Pedagogika wobec zagrożeń, kryzysów i nadziei, ed. T. Borowska, Krakow, 2002, p. 101.

11 J. Gajda, "Samotność", [in:] Encyklopedia pedagogiczna XXI wieku, vol. V, ed. T. Pilch, Wydawnictwo Akademickie Żak, Warsaw, 2003, p. 657. 
ronmental factors that the child has no impact on, especially when it comes to adults - the child needs their attention, support, help, interest in school and life outside school, as well as in contacts with peers and their interests.

For the purposes of this study, the author uses the terms loneliness and isolation interchangeably, understanding them as "a feeling of loneliness, or a mental state characterised by the painful feeling of a lack of bond and regular contact with a person, who is important to the child". ${ }^{12}$ The author decided to do this consciously, knowing that for early school-age children the difference between these concepts may be elusive, and these terms are often used synonymously by adults.

The feeling of loneliness experienced by children can be caused by a number of factors, the most important of which seems to be the weakening of emotional bonds between family and members of their immediate peer group. By analysing the source materials, one can see that new technologies are becoming increasingly important in the lives of Polish families. With every new year, families spend more and more of their free time using new technologies. ${ }^{13}$ The excessive use of the media by children can have a destructive and disintegrating effect on the family - the increasing amount of time devoted to the media can come at the expense of other activities or the time that the child could spend with the family, which can be detrimental to integration, as well as building bonds and relationships within the family.

The media play an important role in the lives of young parents, who use them for work, communication, information and entertainment. Studies show that parents are keen to shift the tasks that until recently were their parental responsibilities - education, playing and making sure the child is occupied in their free time is in-

12 M. Łopatkowa, Samotność dziecka, Wydawnictwo Szkolne i Pedagogiczne, Warsaw, 1983, p. 4.

13 D. Batorski, “Technologie i media w domach i życiu Polaków”, [in:] J. Czapiński, T. Panek (eds.), Diagnoza społeczna 2015: Warunki i jakość życia Polaków, pp. 355-377, Warsaw: Rada Monitoringu Społecznego, 2015. 
creasingly associated with the use of digital tools in younger and younger children. Parents themselves admit that they use new media to capture the child's attention, to calm them down, to claw back some time for themselves, or to take care of other, more urgent matters. ${ }^{14}$

Children are increasingly exposed to contacts with new technologies even in the cases where this happens unintentionally. Additionally, they participate passively in the use of digital tools smartphones, tablets, computers - by their guardians (parents, older siblings, grandparents). ${ }^{15}$ Watching adults in the digital world, even the youngest children can become convinced that the world offered by the media is more interesting than offline life, that media is a great tool that provides fun and entertainment, while warding off boredom. In many cases, children who are left to their own devices reach for digital devices which, unlike their parents, are always present and always ready to fill their time. According to Izdebska: "Having loved ones and feeling lonely is the worst kind of loneliness, because it kills one's hope, weakens motivation, deforms mentally". ${ }^{16}$ At the same time, the lack of time for children is turning into a negative symbol of our contemporary life, resulting in a sense of loneliness among family members. While spending their time alone, even in spite of not being physically separated from their parents, children experience a sense of injustice, rejection, alienation.

The media and digital devices seem to have become an alternative, which helps children alleviate and overcome this feeling. This gives rise to a kind of paradox - in order to fill the emotional void, children use digital devices, drifting even further away not only from their parents but also from their peers.

14 D. Batorski, “Technologie i media w domach i życiu Polaków”, [in:] J. Czapiński, T. Panek (eds.), Diagnoza społeczna 2015: Warunki i jakość życia Polaków, pp. 355-377, Warsaw: Rada Monitoringu Społecznego, 2015.

15 J. Marsh, P. Hannon, M. Lewis, L. Ritchie, “Young children's initiation into family literacy practices in the digital age", Journal of Early Childhood Research, p. 1-14, 2015.

${ }^{16}$ H. Izdebska, “Współżycie pokoleń w rodzinie”, Problemy opiekuńczo-wyychowawcze, 1980, no. 9 . 
Parents are increasingly absent from their children's experiences, which are now largely related to the digital messages they receive. The lack of knowledge about the media among the parents, combined with a lack of appropriate role models to learn how to properly and safely use the new media lead children to watching animated films in the TV and YouTube videos, playing video games and using social networking sites on their own, without any supervision. Many parents do not even try to explore this world, leaving children completely unattended. They do not talk to children about what they do online, they do not explain the digital world, they do not know what makes children happy in this world, what makes them very emotional, what makes them anxious and worried. Such an attitude not only fosters discouragement, indifference and distrust in children, but also leads to the loosening of the psychological bond between parents and their children.

One of the most common accusations levelled against the media is that they significantly damage social contacts and adversely affect the emotional life of their users. Maciej Tanaś lists a number of potential threats and risks, such as social alienation and weakening of family ties or social relations in general, as well as escapism from the real world into the world of media. ${ }^{17}$ Undoubtedly, the digital community in which a child lives also affects their relationships with peers, since young people shape their psyche in their relationships with the group, and this process usually occurs in school. The use of media or specific digital content is a topic, which frequently pops up in conversations among early school age children. They devote a lot of time to that topic in their conversations: they analyse videos watched on YouTube, clips recorded on TikTok, as well as photos and accounts published on Instagram. New technologies can also help children to acquire a certain position in their peer group. Owning a smartphone, installed apps, video games, a high-end

${ }^{17}$ M. Tanaś, "Primum non nocere a internetowa przestrzeń wolności i aktywności nastolatków", [in:] Nastolatki wobec internetu, NASK, ed. M. Tanaś, Naukowa i Akademicka Sieć Komputerowa, Warsaw, 2015, pp. 48-49. 
computer or tablet often helps them to become a part of a group, to feel like they belong. Like books in the days of old, these days popular children's TV shows, applications and video games form links that connect children to each other, allowing them to communicate and get together on the basis of common interests. Watching shows together or playing popular video games can stimulate conversation just as well as discussing a book people read, since this leads to shared experiences that bring children closer together, giving them joy and laughter. However, it can also lead to fighting for hierarchy in the group, trying to establish one's position in the peer group, due to the urge to dominate over others, humiliating someone in a computer game, as well as boasting about one's digital skills. This situation also leads to the risk of social exclusion of those children who do not have access to digital tools - social ostracism caused by the lack of a fashionable phone, popular game or app can even lead to extreme situations such as bullying or theft of desired devices. It can also be a reason for the child to be rejected by a peer group and, as a result, lead to a feeling of loneliness.

\section{Study results}

In 2019, the author carried out qualitative studies in two primary schools in Poznan. The aim of the study was to examine and describe whether the digital environment and the use of new technologies can contribute to a sense of loneliness among early school-age children.

Thus formulated study objective required the author to identify research problems:

1. How do early school-age children perceive loneliness and isolation?

2. Do children connect a sense of loneliness with digital media?

In order to answer the study questions, the author used focus group interviews with children (also known as focus group, group discussion, focus or focus study), which can be considered as 
a communicative data collection technique. ${ }^{18}$ This type of interview enables interaction and discussion within the group, ${ }^{19}$ as well as offers direct access to facts, with the additional benefit that the information obtained is accurate and reliable. The focus study was carried out according to the prepared set of instructions with special care and conditions for a good interview with the child. The study involved 30 primary schoolchildren attending the 3rd grade. In the study, the author selected a targeted study group, based on the age of children, the number of children examined in the study, their respective genders and the schools in which the study took place. The author set up 5 focus groups, with six children in each group, which allowed to keep the atmosphere of intimate closeness and openness. The children chosen for the study attended integration classes, and the study group involved 15 boys and 15 girls. For the purpose of this paper, children's statements are quoted without the codes assigned to them during the study.

\section{Perception of loneliness and isolation by early school-age children}

Early school-age children not only perfectly understand the concept of loneliness, but also declare that they experience loneliness themselves. When asked the question about the meaning of loneliness, they responded with: "it's about being sad", "it's being alone all the time", "it's a kind of a pain in your heart, because a person is alone". They also know where loneliness comes from: "It's a sad feeling when nobody wants to play with you or talk to you", "it's when you're standing alone in the classroom or in the hallway and nobody talks to you", "you're constantly alone, you have no friends", "it's when your parents don't pay attention to you", "it's because parents would rather stare at the TV than

18 S. Banaszak, Technika i jej zastosowanie w badaniach edukacyjnych, Wydawnictwo Naukowe UAM, Poznań, 2017.

${ }^{19}$ R.A. Krueger, M.A. Casey, Focus groups: A practical guide for applied research, Sage Publications Inc, Thousand Oaks: 2000. 
play with me", "it's because my mum doesn't even talk to me, she just keeps checking her Facebook"; "when I talk to my mum, and she just nods, I know she doesn't listen to me at all, she's just busy writing something on the Internet or posting pictures on Instagram".

They also know perfectly well what can be done to overcome loneliness: "find a friend", "somebody who likes you", "a person who likes to spend time with you", "somebody who has time for you". Some also referred to new technologies: "To avoid being lonely, you have to find someone, a friend, who would rather talk to you than play with their phone". "I won't be lonely when I get my parents to leave their phones alone and play with me instead". "You have to make friends with somebody and be important to that person. Even more important than recording TikTok clips or posting photos on Instagram". "To not be lonely, you have to like somebody who likes you back, who likes spending time with you and will always choose you, instead of doing stuff on their phone".

The children were also asked about how important it is for them to spend time with other people. If they had to make a choice: unlimited access to media (smartphone, tablet, TV, computer) and a meeting with a friend, what choice would they make? In response, all children declared that they would choose to meet their friend. Why this is the case? Because they miss such contacts, because they feel the need to deepen them, because meetings with their peers at school are not enough for them, because they prefer direct relations with other people to those mediated by the media. The children pointed out that in spite of the fact that technology and media are a great source of entertainment, they largely contribute to their loneliness.

\section{The relationship between loneliness and digital media in children's opinions}

To find out the answers to this research problem, the author asked the children a number of questions. One of the first concerned the reasons for using new technologies at home at all. In their answers, the children pointed out that they use them because of the 
lack of alternative activities, ideas on how to fill their free time, as well as out of boredom. They claim that when left alone, often without the supportive presence of their parents, they choose digital media as an easily accessible means to fill their free time after school; however, they would be happy to exchange them for an opportunity to spend time playing, as well as meeting with their peers or parents:

"If I had to choose whether to play with someone on the console or go out with friends, I would choose my friends, because since I moved here, I rarely get to see someone, I don't know anyone here and I just don't have anybody to go out with, so I'd rather do that than sit home alone and play games".

"I'd always prefer to meet a friend, because often when I watch something, I get bored sitting alone at home. My parents are never there, and I don't know what to do... If I had someone to meet, I would rather choose to play with them, rather than watching animated films and playing games".

When asked if they had ever felt lonely at home, even though their parents were physically close, they replied:

"I often feel lonely, because my mum just sits with her phone and keeps doing something on it, I don't know why. When I ask her, she never shows me and tells me to go and play. I'd rather play with her or play a game together..."

"I get very sad sometimes, because my parents are at home, but they don't care about me at all, they always say 'later, later' and then they do nothing at all. Dad plays games, and mum constantly talks with her friends on Messenger".

Sometimes they experience similar feelings at school or during meetings with their peers. They notice that for many of their peers, their media are so valuable that using them makes them feel lonely:

"Sometimes, when I meet my friends, they pull out their phones and I feel like they don't respect me, they don't see me, they just see their 
screens, that light. It's not a cool feeling... We're supposed to be together, and yet we aren' $t$ ".

"Sometimes when I go outside, I grab my phone, my friends do the same thing and then we don't get bored, because we keep looking at stuff. Despite that, we get kind of bored, because we just stare at our phones instead of talking.

"You can sit in the same room, close to each other, but if you have your computer and phone on, it's like we're not in that room at all. I would always prefer to spend less time with someone, but to be really with each other and do various things together, rather than be with each other, and spend time playing on the phone or on the console".

Children notice that topics concerning digital content dominate in their conversations, at times resulting even in peer exclusion:

"All the guys in class play games, so that's all we talk about. In the other class, there's this boy who doesn't play games. And the guys from his class always stand in a group of four, talking about games, and he doesn't know what they're talking about and he always stands to the side, and he probably feels very lonely".

"At some point, no one wanted to play with me because I didn't watch the film, and the girls didn't want to tell me how to play, I was very sad because I had to stand alone and do nothing".

Although few of them experienced a sense of loneliness at school because of this, children were aware that new technologies could have a real impact on their relationships with peers:

"Phones can make you just look at them, make you never talk to anybody and be constantly alone. The others will eventually start having fun without you..."

"When I visit my friend, and she doesn't even look at me, she just looks at the phone, I don't want to meet with her any more. It's sad, because even when we're walking home from school together, she keeps staring at it all the time. That makes me feel lonely, as if I was alone. I'm with her, but at the same time I'm alone". 
Children's opinions should be an important clue for adults, letting us know that they feel increasingly lonely because of their own contact with the media, as well as that of their adult guardians. Children interact with other people, communicate their social needs and expect them to be satisfied in their closest circles. When the family is unable or unwilling to meet them, they begin to satisfy them somewhere else and in other ways, such as new technologies, which result in a certain paradox - they further exacerbate the phenomenon of loneliness in the digital world.

The last question asked by the author was: "How would you feel if the media disappeared?"

Only three children seemed to worry about such a vision of the world. The remaining children replied: I would be somewhat sad and happy and the same time. At first, the children were confused by that strange question, but then they started to plan their lives without new technologies. They came to the conclusion that - although they would be sad and uncomfortable at the beginning such a situation could result in something good, for example more time spent together with their parents and peers:

"I'd be very sad that I wouldn't be able to record any more TikTok clips, but I could play more board games with my parents, maybe they'd have more time for me. Now it's really not the case, I'm alone all the time".

"It would be a little good and a little bad at the same time. I'd feel desperate... but maybe that could be fun, too? It's because my mum constantly watches the TV, and if that was the case, I could play with my mum, go to the park and spend time together".

"I'd feel sad, I'd miss it a little bit, but if everything disappeared, I think it would be better. No one would bully or insult anybody, there would be no YouTube, everyone would have fun and spend more time together. My parents, for example, could spend more time with me".

In other words, children believe that such an unusual situation could become an opportunity for them to strengthen their relationships and see new opportunities and ways of filling their free time. 
These responses also allowed the author to conclude, contrary to the popular opinion, that children deem the company of their peers and family way more important than using new technologies, which leads to the conclusion that it is the adults who are largely to blame for the fact that children experience loneliness, despite being surrounded by their loved ones.

\section{Conclusions}

Some of the results of the study presented in this paper lead to the conclusion that the digital environment and the use of new technologies can contribute to the feeling of a sense of loneliness among early school-age children.

Children know this feeling, they can not only define it and determine where it stems from (rejection by peers and parents), but they also know what to do in order to counteract and alleviate it (maintaining relationships, entering into relationships and strengthening them in absence of new technologies). One of the reasons for loneliness indicated by children is that they experience loneliness among their family and loved ones. They note that parents increasingly use digital tools in their free time, at the expense of other activities that could be undertaken without said tools, but together, as a family (for example playing or simply spending time together). Feeling more and more lonely, they start using new technologies themselves, and gradually lose control of their time. In their statements, the children indicated that they did not know what could make for a good alternative to digital media, because they have always been present in their lives, and they always associated them with tools used to ward off loneliness and boredom. Children are starting to use new technologies not only at home but also outside their homes, using them to keep in touch with their peers, which may lead to significant consequences in their lives. Excessive use of the media without counterbalancing them with other activities, as 
well as without the supervision of the adults both over the quality and duration of this contact may lead them to experiencing loneliness and estrangement as a result of other members of their peer group, who do not hold the media in such a high regard, leaving them for others. Children notice that excessive immersion in the digital world can lead to loneliness: despite physical closeness - for example, even despite being in the same room, one may feel lonely when other people do not pay attention.

Loneliness can also result from the opposite situation, when a child does not use media and does not have apps, tools or devices popular among their peers. This may lead to social exclusion, resulting in a sense of loneliness.

Both loneliness and isolation usually result from overlapping external factors. This is also the case in this situation - it can be assumed that appropriate digital skills of parents and teachers, their attention and vigilance, could prevent the aforementioned situations leading to loneliness experienced by children in many situations. In social discourse, there is a belief that communication mediated by the media is preferred by children and adolescents, and chosen more willingly than face-to-face communication with other members of society; however, recent studies seem to contradict that hypothesis, showing that children value direct relationships as much as those mediated by the media. ${ }^{20}$ The author reached a similar conclusion in the study, as children knew that the remedy for loneliness is simple - being mindful of them and spending time with them: "I'd like someone to finally pay attention to me. To me, not to the phone".

References

Banaszak S., Technika i jej zastosowanie w badaniach edukacyjnych, Wydawnictwo Naukowe UAM, Poznań, 2017.

${ }^{20}$ D. Boyd, It's Complicated: the Social Lives of Networked Teens, Yale University Press, New Haven - London, 2014, pp. 20-28. 
Batorski D., “Technologie i media w domach i życiu Polaków”, [in:] Diagnoza społeczna 2015: Warunki i jakość życia Polaków, J. Czapiński, T. Panek (eds.), Rada Monitoringu Społecznego, Warsaw, 2015.

Boyd D., It's Complicated: the Social Lives of Networked Teens. New Haven - London: Yale University Press, 2014.

Cassidy J., Asher S.R, Loneliness and peer relations in youth children. Child Development, 63(2), 1992.

Cudak H., Szkice z badań nad rodzina, Wyższa Szkoła Pedagogiczna Kielce, Kielce, 1995.

Dubas E., "Samotność i osamotnienie jako wyznacznik dla dzisiejszej edukacji”, [in:] Pedagogika wobec zagrożeń, kryzysów i nadziei, ed. T. Borowska, Krakow, 2002.

Gajda J., "Samotność", [in:] Encyklopedia pedagogiczna XXI wieku, vol. V, ed. T. Pilch, Wydawnictwo Akademickie Żak, Warsaw, 2003.

Gajewska G., “Opuszczenie i osamotnienie dziecka wśród dorosłych”, [in:] Nowe stulecie dziecku, G. Gajewska, D. Waloszek, (eds.) Zielona Góra, 2001.

Izdebska H., “Współżycie pokoleń w rodzinie”, Problemy opiekuńczo-wychowawcze, 1980, no. 9.

Kozdrowicz E., "Dziecko zagubione w rzeczywistości”, [in:] Nowe stulecie dziecku, G. Gajewska, D. Waloszek, (eds.) Zielona Góra, 2001.

Krueger R.A., Casey M.A., Focus groups: A practical guide for applied research, Sage Publications Inc, Thousand Oaks 2000.

Ladd G.W., Kochenderfer B.J., Coleman C.C., Friendship quality as a predictor of young children's early school adjustment, 67(3), 1996.

Łopatkowa M., Samotność dziecka, Wydawnictwo Szkolne i Pedagogiczne, Warsaw, 1983.

Marsh J., Hannon P., Lewis M., Ritchie L., “Young children's initiation into family literacy practices in the digital age", Journal of Early Childhood Research, 2015.

Matyjas B., Źródta prowadzace do osamotnienia dziecka w rodzinie, Wydawnictwo Uniwersytetu Jana Kochanowskiego Kielce, Kielce, 2011.

Niewiadomska, "Osamotnienie - sprzyja toksykomanii", Problemy Alkoholizmu, Warsaw, 1994, no. 8-9.

Pyżalski, J., Zdrodowska, A., Tomczyk, Ł., Polskie badania EU Kids Online 2018. Najważniejsze wyniki i wnioski, Warsaw, Fundacja Orange, 2019.

Szczepański J., Sprawy ludzkie, Wydawnictwo Czytelnik, Warsaw, 1980.

Tanaś M., “Primum non nocere a internetowa przestrzeń wolności i aktywności nastolatków", [in:] Nastolatki wobec internetu, NASK, ed. M. Tanaś, Naukowa i Akademicka Sieć Komputerowa, Warsaw, 2015. 